\title{
ESTRATÉGIAS DE REGULARIZAÇÃO FUNDIÁRIA PATRIMONIAL ANTES DO ADVENTO DAS LEIS 11.977/2009 E 13.465/2017: UM ESTUDO DE CASO DA ATUAÇÃO DO ORGÃO DE TERRAS DO ESTADO DO PARÁ
}

\author{
PATRIMONIAL LAND REGULARIZATION STRATEGIES BEFORE THE \\ ADVENT OF LAWS 11.977/2009 AND 13.465/2017: A CASE STUDY OF THE STATE OF \\ PARÁ LAND ORGAN ACTUATION
}

Luly Rodrigues da Cunha Fischer

\begin{abstract}
Doutora em Direito pela Universidade Federal do Pará (UFPA) e Universidade de Paris XIII (2014) em regime de cotutela. Possui Graduação (2005) e mestrado em Direito (2008) pela UFPA. Atualmente professora adjunta do Instituto de Ciências Jurídicas da UFPA (Graduação e Pós-Graduação), advogada inscrita na Ordem dos Advogados do Brasil, membro do Instituto Brasileiro de Direito Urbanístico e do Instituto Histórico e Geográfico do Pará. Membro da Rede de Pesquisa Junction Amazonian Biodiversity Units Research Network Program (JAMBURNP) e dos Grupos de Pesquisas Biodiversidade, Território e Sociedade na Amazônia (BEST AMAZÔNIA). E-mail: lulyfischer@yahoo.com

Erica Ferreira dos Santos

Graduanda no Curso de Direito da Universidade Federal do Pará - UFPA. Atuou como Bolsista no Projeto de Pesquisa Apuração do Remanescente da $1^{a}$ Légua Patrimonial de Belém: identificação dos limites da Primeira Légua Patrimonial e de sua afetação ao Uso Público, orientada pela Prof ${ }^{a}$ Dra. Luly Rodrigues da Cunha Fischer, vinculada a Clínica de Direitos Humanos da Amazônia - CIDHA, do Instituto de Ciências Jurídicas da UFPA/PPGD. É Colaboradora na Comissão de Meio Ambiente da Ordem dos Advogados do Brasil - OAB/PA e membro da Liga Acadêmica Verde Cabanagem na linha de Pesquisa Direito Urbanístico. E-mail: ericafsantos16@gmail.com
\end{abstract}

Recebido em: 19/04/2018 Aprovado em: 13/12/2018

RESUMO: Analisa o processo de regularização fundiária urbana de bens públicos feito pelo Estado do Pará, ocorrida em Belém (1992-2002) e faz um prognóstico dos efeitos da Lei n. 13.465/2017 para a atuação estatal. A utilização da base legal de titulação como parâmetro teve o objetivo de demonstrar sua contribuição para a garantia do direito social a moradia, considerando que se constitui na mais recente disposição legal sobre o tema. Utiliza o método dedutivo de abordagem, o estudo de caso como método de procedimento e as técnicas de pesquisa bibliográfica e documental. Por meio do estudo de caso conclui que as transferências por doação no Estado foram utilizadas para promover programas de regularização fundiária urbana, mas na ausência de legislação específica para seu emprego para fins urbanísticos fez com que a fundamentação legal das transferências fosse inadequada. Nesse contexto a Lei n. 13.465/2017 terá impacto positivo para o Estado do Pará, uma vez que permitirá uma destinação patrimonial em áreas urbanas sem vícios formais para a titulação de projetos de regularização fundiária urbana.

Palavras-chave: Regularização Fundiária Estadual. Doação. Área Urbana. Belém.

ABSTRACT: Analyzes the process of urban land regularization of public property made by the State of Pará in Belém (1992-2002) and make a prognosis of the effects of law 13.465/2017 for State action. The use of the legal basis of titration as parameter aimed to demonstrate your contribution to the guarantee of the social right to housing, whereas it is in the most recent legislative provision on the subject. Uses the deductive method of approach, the case study as a method of procedure and techniques of bibliographic and documentary research. Through the case 
study concludes that the transfers by donation in the State were used to promote urban agrarian regularization programs, but in the absence of legislation specific to your job for urban purposes made the legal reasoning of the transfers were inadequate. In this context the law 13.465/2017 will have positive impact to the State of Pará State, since it will allow for asset disposal in urban areas without formal defects for the titration of urban land property regularization projects.

Keywords: Urban land regularization. Donation. Urban area. Belém.

SUMÁRIO: Introdução. 1. A Doação de Bens Públicos. 2. Legislação Estadual de Doação de Terras. 3. Regularização Fundiária Urbana e a Lei n. 13.465/2017. 4. Atuação Estadual em Regularização Fundiária Urbana: Estudo de Caso do Município de Belém. Conclusão. Referências.

\section{INTRODUÇÃO}

A doação de bens imóveis públicos é umas das formas de alienação utilizadas historicamente pelo Poder Público para povoação e ordenação do território. Embora seu uso seja pouco estudado pelo Direito Urbanístico, trata-se de uma das formas mais frequentes de alienação do patrimônio público em processos de regularização fundiária urbana no país.

O presente artigo possui o objetivo de analisar a regulamentação da doação de bens imóveis na legislação do Estado do Pará, antes do advento da Lei n. 13.465/2017, a qual redefiniu meios e instrumentos para a regularização fundiária urbana e rural. Com a análise busca-se verificar como as alienações foram realizadas e se houve observância as normas gerais sobre o assunto pelo Estado do Pará nessas transferências.

A regularização fundiária é um processo que inclui medidas jurídicas, urbanísticas, ambientais e sociais, com o intuito de integrar assentamentos irregulares ao contexto legal das cidades. É a base para a garantia do direito social a moradia, tendo em vista a emergente necessidade de ordenar as cidades e enfrentar problemas sociais, estruturais e ambientais decorrentes da ausência de investimento e atenção do poder público à população urbana.

No Estado do Pará, a regularização fundiária em áreas urbanas é relativamente recente, pois a princípio não se dissociavam as necessidades urbanas e rurais de ordenação do território. Com o desenvolvimento urbano e acirramento de questões estruturais decorrentes da precariedade de moradias e informalismo, foi necessário maior atenção ao âmbito urbano.

Nesse sentido, a temática proposta se mostra relevante, pois há poucos estudos empíricos na área do direito sobre o emprego da doação enquanto instrumento para a regularização fundiária de bens públicos.

O estudo fornecerá ao Estado do Pará um histórico fundiário urbano sobre o uso da doação para transferência de bens públicos e o estudo de caso demonstrará qual o impacto das doações analisadas para área urbana do Município de Belém, especialmente no que concerne a existência de interesse público, a garantia do direito social a moradia e o atendimento da função social da propriedade. Como reflexo, demonstra aos demais Estados a necessidade de compreender a importância da doação para a realidade fundiária de seus territórios.

Essa avaliação torna-se peculiarmente relevante com o advento da Lei Federal n. 13.465/2017, em que foram ampliadas as possibilidades de transferência de domínio pleno, inclusive por meio de aquisição originária, como é o caso da legitimação fundiária.

Neste estudo, partiu-se do pressuposto que a doação de bens públicos se pauta em uma relação de liberalidade entre Poder Público e particulares singularmente, regida pelas regras gerais de Direito Privado e de Direito Público, sem, contudo, possuir uma normatização específica para seu emprego em projetos de regularização fundiária.

Na prática será demonstrado que a doação consolidou-se como um instrumento comum e largamente utilizado pelo Poder Público para alienação gratuita e regularização fundiária de bens públicos, revelando o presente artigo uma realidade pública e social ainda não desvendada. 
A construção desta pesquisa será orientada a partir do método de abordagem dedutivo (MARCONI; LAKATOS, 2010, p. 65-96), utilizando como método de procedimento o estudo de caso (YIN, 2015, p. 1-25). Como técnicas de pesquisa utilizou-se a pesquisa bibliográfica e documental. $\mathrm{O}$ emprego da primeira técnica objetivou traçar um panorama doutrinário de como esta juridicamente fundamentada no país esta forma de transferência.

O levantamento documental consistiu no levantamento das normas estaduais e federais, bem como no levantamento dos títulos de doação emitidos pelo Estado do Pará entre os anos de 1992 a 2002 na área urbana do Município de Belém e teve por intuito analisar se as transferências realizadas observaram ou não a legislação nacional e estadual vigente.

A apresentação deste artigo está organizada em quatro partes. Primeiro é feita uma revisão bibliográfica sobre a doação de bens imóveis públicos, na qual serão analisados os seus critérios e hipóteses de utilização, bem como os posicionamentos da doutrina sobre o tema. Em seguida, é apresentada a regulamentação legal do Estado do Pará sobre a doação de bens entre 1891 a 2009. Na terceira parte são analisadas as disposições sobre a regularização fundiária urbana presentes na Lei n. 13.465/2017, considerando as mudanças e inovações em relação à Lei n. 11.977/20019, no que tange a doação e a regularização fundiária urbana, e seu impacto para a aplicação da legislação estadual em vigor. Por fim, apresenta-se o estudo de caso do Município de Belém.

\section{A DOAÇÃ̃ DE BENS PÚBLICOS}

A origem da doação de bens públicos situa-se no contexto da história de ocupação territorial brasileira a partir dos anos de 1500, período em que a Coroa Portuguesa intensificou suas expedições em busca de terras e riquezas. Como destaca Garcia (2009, p. 1162), as extensões de terras descobertas passavam a integrar o domínio da Coroa Portuguesa, isto é, na origem do país todos os imóveis eram de titularidade da Coroa e não existiam terras privadas.

Com a finalidade de ocupar estrategicamente os territórios, a Coroa Portuguesa transferiu propriedade de terras a particulares, processo que teve início com o sistema de capitanias hereditárias, no qual como descreve Marques Neto (2009, p. 88), se transferia bens a donatários a quem se dava a prerrogativa de dar e conceder extensões territoriais a quem quisesse cultivar por meio do sistema de sesmarias, o que proporcionava renda ao poder local.

A gestão dos bens públicos exercida com titularidade pelo Estado, sob as diretrizes do Direito Público, o tornou figura legítima para promover alienações e transferências a terceiros, bem como desapropriações, com fundamento em seu poder de império e na supremacia do interesse público. A doação figura, portanto, como uma forma que possibilitou ao Estado, a partir de interesse motivado, dispor de seus bens em favor de outrem.

A natureza jurídica da doação de bens originariamente se encontra no direito civil, o qual a regulou anteriormente ao direito administrativo. O Código Civil de 2002 a define no art. 538 como um contrato que possui como característica principal a liberalidade (GONÇALVES, 2012, p. 283).

Conceitualmente ela é definida como:

[...] contrato segundo o qual uma pessoa, chamada doador, por liberalidade transfere um bem do seu patrimônio para o patrimônio de outra, designada donatário, que o aceita. Tanto o doador como o donatário podem ser pessoas físicas ou jurídicas e estas, públicas ou privadas. (GASPARINI, 2003, p. 705)

Deste modo, pontua-se que pode o Estado como ente público doar, mas também receber doações, figurando como doador ou donatário na relação jurídica.

No que tange a alienação gratuita às pessoas jurídicas, interessante a análise feita por Vasconcelos e Fischer (2016, p. 73) sobre a doação pelo Poder Público a entidades religiosas, pois esclarecem que em atenção ao princípio da laicidade e demais princípios constitucionais da 
Administração pública, é vedada a doação de terrenos públicos a entidades religiosas, salvo nos casos em que houver interesse público devidamente motivado, pautado no bem da coletividade $\mathrm{e}$ não em status confessional de um grupo religioso, para evitar sobretudo que esse promova tratamento distintivo entre brasileiros.

Como explica Gomes (2009, p. 255), a transferência da propriedade do bem por doação a outra pessoa quando se tratar de bem móvel ocorre com a tradição, isto é, a entrega da coisa, e se o bem for imóvel pela transcrição, que será a modificação da inscrição da matricula do imóvel do nome de quem doa para o de quem receberá a doação.

A natureza jurídica da doação de bens públicos no direito administrativo, que trata das possiblidades de alienações e transferências pelo Poder Público, é contratual, cuja espécie é de contrato de direito privado ou contrato privado da administração (CARVALHO FILHO, 2014, p. 174). Isto porque, é regida pelo direito civil, mas são parcialmente regulados pelo direito público, o que lhes atribui características existentes neste âmbito do direito (DI PIETRO, 2014, p. 268).

No que concerne à possibilidade de doação de bens públicos, destaca-se que são os bens de domínio nacional pertencentes a pessoas jurídicas de direito público interno, conforme o art. 98 do Código Civil. São todas as coisas corpóreas e incorpóreas, móveis e imóveis, que pertençam aos entes estatais e formem o domínio do Estado, considerados por princípio inalienáveis, e por isso, não estão disponíveis para alienação em favor de terceiros.

A Constituição Federal de 1988 concedeu proteção especial aos bens públicos, vedando sua aquisição por usucapião (art. $183 \$ 3^{\circ}$ e 191) em face dos princípios da indisponibilidade, supremacia do interesse público e legalidade. Assim, deve ser prioridade da Administração pública a preservação destes princípios, que funcionam como limitação à alienação de bens públicos a terceiros, sendo sua transferência admitida apenas em casos excepcionais, quando houver fim público que justifique seu uso privativo.

Neste intuito, definiu como regra a licitação para alienações e contratações públicas (art. 37, XXI) incumbindo à União a competência para legislar sobre normas gerais de licitação (art. 22, inciso XXVII), permitindo, contudo, aos Estados legislar sobre questões específicas à matéria (art. 22, XXVII), o que se aplica a alienação de bens públicos, que deverá observar a Constituição Federal, as Leis federais, bem como as normas específicas editadas pelos Estados.

A doação de bens públicos enquanto forma de alienação deve obedecer às regras de licitação, observar as restrições de inalienabilidade e vislumbrar o atendimento da função social da propriedade.

Cumpre destacar que a transferência de bens imóveis públicos por doação, como um contrato de natureza civil deve observar ainda a Lei de licitações nº 8.666/1993.

A Lei de licitações e contratos administrativos em atenção à Constituição Federal disciplinou regras de licitação a ser seguidas pela Administração pública e para aqueles que desejam contratar com a Administração e também dispôs sobre a doação dos bens da União. Para a alienação de bens públicos, exigiu a estrita subordinação ao interesse público devidamente justificado, descrevendo dentre outros instrumentos para a alienação a venda, doação, dação em pagamento e permuta.

A Lei Federal determinou ainda que a alienação de bens públicos imóveis depende de licitação na modalidade concorrência, avaliação prévia, e ainda autorização legislativa se tratando dos órgãos da Administração direta e entidades autárquicas e fundacionais (art. 17, I), contudo ressalvou exceções em que a licitação poderá ser dispensada, como nos casos de doação permitida estritamente a outro órgão ou entidade da Administração pública em qualquer esfera de governo (alíneas "a" até "h").

A lei também dispensou licitação para alienação gratuita ou onerosa de bens imóveis, o que se enquadra como doação, com a finalidade de serem utilizados em programas habitacionais ou de regularização fundiária de interesse social, desenvolvidos por órgãos ou entidades da Administração pública, (alínea “f”, inciso I do art. 17). 
Neste sentido dispôs que deve haver reversão dos bens ao patrimônio da pessoa jurídica doadora, quando cessarem as razões que justificaram a doação, inclusive restando vedada sua alienação ( $\$ 1^{\circ}$ do art. 17). O disposto contido no $\S 1^{\circ}$ teve seus efeitos suspensos em julgamento do Supremo Tribunal federal na ADIN n. 927-3 de 03 de novembro de 1993, mas persistiu o entendimento quando se tratar de bens da União.

A alienação gratuita ou onerosa de bens imóveis de uso comercial de âmbito local foi permitida quando em área de no máximo $250 \mathrm{~m}^{2}$ (duzentos e cinquenta metros quadrados), inseridos em programas de regularização fundiária de interesse social desenvolvidos por órgãos ou entidades da Administração pública, assim como a alienação gratuita ou onerosa de terras públicas rurais da União na Amazônia legal, onde existam ocupações até o limite de 2.500 ha (dois mil e quinhentos hectares), com a finalidade de regularização fundiária (alíneas " $h$ " e "i").

A Lei ainda dedicou dispositivo específico sobre a doação com encargo, a qual deve ser licitada e necessita constar em seus instrumentos os encargos, o prazo de seu cumprimento e cláusula de reversão, sob pena de nulidade do ato. No entanto, quando presente interesse público devidamente justificado, a licitação é dispensada (art. 17, $\$ 4^{\circ}$ ).

Carvalho Filho (2014, p. 1212) destaca que embora a Lei de licitações tenha sido editada dentro da competência federal para instituir normas gerais, se excedeu na disciplina e criou regras específicas como no caso do destinatário da doação, de modo que para quaisquer alienações de bens públicos deve-se vislumbrar o que determina a Constituição Federal e a Lei de licitações.

No que concerne a doação de bens públicos, Uchoa e Rodrigues (2016, p. 561) ao analisar a Lei $n^{\circ}$ 8.666/1993 esclarecem:

\begin{abstract}
De modo geral, a doação de bens públicos, para ser lícita, necessita de desafetação, prévia autorização legislativa, avaliação, procedimento licitatório e atendimento do interesse público. A inalienabilidade dos bens é relativa, pois conserva tal característica enquanto destinado ao uso comum ou ao serviço público. Todavia a questão da doação dos bens públicos deve ser analisada sob duas perspectivas: da regularização fundiária e do desenvolvimento sustentável das cidades.
\end{abstract}

Marrara (2007, p. 115) explica que para a possível transferência de bens públicos é necessário a quebra da inalienabilidade, a qual ocorre com a desafetação do bem, devendo-se entender que a afirmação de que a inalienabilidade dos bens públicos é absoluta, não significa que estes não podem ser alienados, mas que é possível a transferência do bem, desde que se transformem em bens do domínio privado estatal ou bens particulares, alterando seu status de dominialidade.

Apesar de legítima, a doação de bens públicos pela Administração encontra posições acauteladoras na doutrina, no sentido de que deve ser evitada como forma de transferência de bens públicos. Este posicionamento é manifestado por Carvalho Filho (2014, p. 1215), que sustenta sua substituição pela concessão de direito real de uso, pelo qual o ente não perderia o patrimônio de seu domínio.

Neste sentido, destacam os autores Farias e Rosenvald (2015, p. 743):

Por lógico, a doação de bem público pressupõe a compatibilidade do ato com o interesse social e com o desempenho das funções estatais, além do atendimento das regras legais, sob pena de desconstituição da avença. Não se tolera, naturalmente, a prática de liberalidades com bens públicos, em prol de interesses particulares, sob pena de nulidade do negócio jurídico.

Desta forma, o uso da doação como forma de transferência de bens públicos deve estar associado à existência de interesse público e uma necessidade social existente.

A doutrina civilista em geral (GONÇALVES, 2012, p. 286; GOMES, 2009, p. 257) enumera diversas formas em que pode caracterizar-se a doação, e no que tange a doação de bens 
públicos, destacam-se como modalidades possíveis a doação pura e simples e a doação modal, onerosa, com encargo ou gravada, pois se compreende que estas são as formas cabíveis de doação de que poderá valer-se o Poder Público para alienar bens públicos, pois permitem ao ente público contemplar fim específico, respeitando o interesse da coletividade.

Na doação pura e simples predomina a liberalidade, pois o doador não impõe encargos ao beneficiário, tendo efeito imediato a partir de sua aceitação (GONÇALVES, 2012, p. 286). Por meio desta, é possível, por exemplo, dispor de um bem em favor de terceiro com o objetivo de garantir seu direito à moradia, existindo a presença de interesse público justificado no que concerne à defesa de direito latente.

A doação com encargo é aquela em que o doador impõe ao donatário um dever a ser cumprido (GONÇALVES, 2012, p. 286). Sua utilização pelo Poder Público pode ocorrer ao dispor de bem sob a condição de que o donatário construa uma quadra de esportes, fim do qual não poderá se eximir, e assim também estaria contemplando o interesse coletivo.

Na prática, explicam Farias e Rosenvald (2015, p. 744) que caso o donatário do bem público deixe de cumprir o encargo imposto, haverá reversão da doação, a fim de garantir o interesse público. Ocorre também à reversão caso o donatário dispunha do bem, e em ambos os casos, cessarão as razões determinantes da celebração do contrato.

Outras formas de doação previstas na Lei civil, como a doação remuneratória ou com cláusula de reversão, por exemplo, não seriam adequadas como formas de doação de bens públicos, pois são específicas e com uso próprio das relações privadas, nas quais se pretende favorecer parte específica da relação contratual.

Como causas de revogação da doação há a por razão de ingratidão do donatário e inexecução do encargo, conforme o art. 555 do Código civil e devido sua natureza contratual, pode ser revogada pelos vícios atinentes aos demais contratos que corroboram em anulação.

No que concerne às normas de Direito Público, além da extinção usual por cumprimento de seus efeitos ou pela extinção objetiva e subjetiva, existem como formas de extinção dos atos do Poder Público a anulação, a revogação, a cassação, a caducidade e ainda a contraposição (DI PIETRO, 2014, p. 247 - 248).

Diante do exposto, salienta-se que a doação de bens públicos possui como característica principal ser uma forma de alienação realizada pela Poder Público a título gratuito, com o objetivo de transferir bem a beneficiário, possuindo natureza jurídica de contrato de direito privado. Dentre as formas de doação, a pura e simples e onerosa são as mais utilizadas pelo Poder Público, embora existam posições doutrinárias no sentido de que seria preferível o uso da concessão de direito real de uso, em que o domínio do bem permanece sob titularidade do Poder Público.

A exposição da doação enquanto forma possível de ser utilizada para a transferência de bens públicos é importante para compreender como as leis que a seguir serão expostas foram permitindo esta possibilidade, bem como para depreender como se tornou um instrumento para a regularização fundiária urbana.

\section{LEGISLAÇÃO ESTADUAL DE DOAÇÃO DE TERRAS}

A primeira disposição legal no âmbito das leis do Estado do Pará sobre a doação foi o Decreto $\mathrm{n}^{\mathrm{o}} 410$ de 08 de outubro de 1891, o qual determinou que seriam legitimadas as partes de sesmarias ou de outras concessões do governo com cultura efetiva e morada habitual, transferidas por título de compra, herança, doação ou outro título condizente com as formalidades (art. $2^{\circ}, \S \S$ $1^{\circ}$ e $2^{\circ}$ ). Houve nesse decreto, portanto, o reconhecimento da concessão de títulos por doação e sua possível legitimação.

A Lei $n^{\circ} 824 / 1902$ autorizou o governo a conceder títulos definitivos de propriedade sem qualquer indenização aos ocupantes de diversos núcleos coloniais. Requereu para isso, que estivesse ocupando o lote em período superior a um ano, possuísse morada habitual e cultura 
efetiva. O indivíduo que recebesse o lote não poderia vendê-lo ou abandoná-lo durante o prazo de um ano, caso contrário teria a concessão anulada e o título cassado. A concessão gratuita incluía a casa de residência caso houvesse, mas não benfeitorias, como máquinas que fossem propriedade do Estado (art. $2^{\circ}$ a $4^{\circ}$ ).

Esta teve grande relevância, pois conforme Palma Muniz (1907, p. V) foram expedidos 1.711 títulos gratuitos no período de 1901 a 1906, e houve uma grande atividade no serviço de terras do Estado.

Em 9 de outubro de 1914 a Lei no 1.423 autorizou, em qualquer Município do Estado, a concessão gratuita de lotes de terras devolutas e estabeleceu como limite 100 (cem) hectares cada lote, dado a todo cidadão que o requeresse. A Lei priorizava o cidadão que não possuísse nenhum terreno do Estado e este ficava obrigado a cultivar o lote no prazo máximo de três anos e demarcálo em até cinco anos (art. $1^{\circ}$ a $3^{\circ}$ ). A Lei $n^{\circ} 1.423$ foi revogada pela Lei $n^{\circ} 1.584$ de 26 de setembro de 1917, a qual tratava da concessão de lotes de terras devolutas.

Em 31 de janeiro de 1921 foi editado o Decreto $n^{\circ} 3.791$, que ratificou o decreto $n^{\circ}$ 410/1891 e adicionou considerações sobre o registro de terras, ressaltando a obrigatoriedade aos possuidores de terras em obtê-lo. Considerou títulos de legítima propriedade para fins de inscrição nos livros de registro de títulos de propriedade do Estado, a escritura pública de doação (art. 180, $\left.\S 6^{\circ}\right)$.

A Lei $\mathrm{n}^{\circ} 762$ de 10 de março de 1954, definiu que ocupantes de terras públicas portadores de títulos de posse expedidos de acordo com a Lei $\mathrm{n}^{\circ} 1.850$, ou portadores de títulos de acordo com os regulamentos vigentes depois da Proclamação da República e bilhetes de localização em lotes agrícolas, que tivessem nestas realizado benfeitorias, poderiam requerer do Governo do Estado o título definitivo de aquisição das mesmas (art. $1^{\circ}$ ).

A Lei n ${ }^{\circ} 1.137$ de 11 de março de 1955 definiu que as alienações dependeriam de prévia avaliação pela Procuradoria Fiscal do Estado (art. $3^{\circ}$, caput), e estabeleceu como competência da Secretaria de Obras, Terras e Viação a defesa do patrimônio do Estado, em empenhar-se para preparar o sistema cadastral de propriedade imóvel.

A Lei ${ }^{\circ} 3.641$ de 5 de janeiro de 1966 regulamentada pelo Decreto $n^{\circ} 5.780$ de 27 de novembro de 1967, trouxe maiores especificações no que tange a doação de imóveis. Classificou, dentre outras como terras públicas as áreas de terras concedidas sob o regime de título de doação, e elencou dentre as demais hipóteses que as terras públicas poderiam ser objeto de doação (art. $2^{\circ}$, alínea "c" e 4", alínea "a").

A doação poderia ser feita a todo cidadão que, domiciliado e residente em uma determinada área de terra, a tivesse tornado produtiva com seu trabalho, nela possuindo moradia habitual e cultura efetiva, anterior à Lei no 3.641/1966, não sendo proprietário rural (art. $6^{\circ}$, caput). Dispôs ainda que a área objeto de doação gratuita poderia ser de até 25 (vinte e cinco) hectares, sendo possível elevação a 100 (cem) hectares, em regiões de família numerosa ou quando a cultura ou a criação exigisse $\left(\operatorname{art} .6^{\circ}\right.$ e $\left.7^{\circ}\right)$.

Os títulos recebidos por doação gratuita só poderiam ser alienados a terceiros após o prazo de três anos de sua expedição, assegurando-se o direito de perempção ou preferência do Estado na transação previsto no art. 1.149 do Código Civil de 1916 (art. $12, \S \S 1^{\circ}$ e $2^{\circ}$ ).

A doação onerosa era também prevista na Lei no $3.641 / 1966$, permitida a todo cidadão que não fosse proprietário rural, e desejasse cultivar e fazer criação efetiva em determinada área de terras, com a finalidade de torná-la produtiva com seu trabalho. Para este tipo de doação, era imposto como limite 100 (cem) hectares em áreas de terras (art. 13 e $14^{\circ}$ ).

Esta possuiria prazo de três anos a contar de sua concessão, prazo no qual o donatário deveria cumprir o que foi proposto e acordado sob pena de incorrer em mora, o que caso ocorresse, revogaria a doação e consequentemente haveria o retorno do imóvel ao domínio do doador (art. 15, caput e $\S$ único). 
Em 22 de agosto de 1969 foi promulgado o Decreto-Lei n ${ }^{\circ}$ 57, o qual considerou que poderiam ser objeto de doação a título gratuito as terras devolutas do Estado, na condição em que o posseiro tivesse moradia habitual ou cultivo de lavoura, contudo ressalvou que a alienação neste caso específico independeria de autorização legislativa (art. $10^{\circ}$, caput).

O Decreto $n^{\circ} 7.454$ de 19 de fevereiro de 1971, que regulamentou o referido Decreto-Lei, dispôs que o Estado poderia doar até 100 (cem) hectares de terras aos posseiros que nestas possuíssem cultivo de lavoura ou morada habitual (art. $5^{\circ}$, caput).

Para que fosse aceito o pedido de doação, o Decreto fez algumas ressalvas (art. $7^{\circ} \S \S 1^{\circ}$, $2^{\circ}$ e $3^{\circ}$ ), como a declaração pelo interessado se era a primeira vez que pleiteava a doação de terras do Estado e caso já tivesse recebido área anteriormente, deveria esclarecer qual o resultado do pedido e o destino dado a terra recebida. Esse decreto também ratificou a impossibilidade de alienação "inter vivos" antes do período de três anos a partir da expedição do título.

Importante salientar que até a legislação supracitada, as leis não determinavam especificamente que suas disposições se direcionavam a área urbana ou rural, apresentando caráter geral, sendo apenas ressalvada a necessidade de o beneficiário da doação não ser proprietário rural, assim como não havia previsão legal expressa direcionada a possibilidade de pessoa jurídica receber doação do Estado, pois o donatário da doação sempre figura como "cidadão" ou "posseiro".

Em 08 de outubro de 1975 foi criado o Instituto de Terras do Pará (ITERPA) ${ }^{1}$, através da Lei $n^{\circ} 4.584$, o qual extinguiu a Secretaria de Agricultura e modificou o Decreto-Lei $n^{\circ}$ 57/69. Em seu ato de criação foi autorizado livremente a alienar até 5 (cinco milhões) de hectares de terras devolutas, para alienações em que o Poder Legislativo não houvesse concedido autorização específica. Definiu-se também que todos os processos agrários em tramitação, nos quais tivesse sido expedido título provisório, fossem encaminhados ao ITERPA para expedição dos títulos definitivos, respeitadas as demais exigências legais (art. 21 e $\S 1^{\circ}$ ).

Determinou ainda que nos processos pendentes, quando comprovada a existência de posseiros que tenham morada habitual ou cultivo de lavoura até 100 (cem) hectares, caberia à Autarquia promover "ex-ofício" ou a requerimento do interessado, a legalização gratuita (art. 103).

Ressalta-se que, até o período das leis citadas acima, não havia no âmbito federal legislação que dispusesse sobre a doação de bens públicos com grande especificidade, inclusive quando situada no contexto da área urbana.

Nesse contexto, havia a necessidade de se abordar o tema direito à moradia e a regularização fundiária urbana no ordenamento jurídico brasileiro, pois a sociedade vivia a ausência de políticas públicas habitacionais, carência de infraestrutura com o aumento de habitações irregulares, falta de atenção dos Estados e Municípios, acirramento de desigualdades e exclusão social em decorrência dos conflitos fundiários, representando a Constituição Federal um marco para o desenvolvimento de legislações e políticas públicas que dessem importância a moradia como um direito social e humano (ZARELLI; ARAÚJO JÚNIOR, 2017, p. 44).

Com a promulgação da Constituição Federal de 1988, a doação de bens públicos foi reconhecida como forma de alienação, que assim se constituindo, deve obedecer às regras de licitação, observar as restrições de inalienabilidade e vislumbrar o atendimento da função social da propriedade (art. 37, XXI), sendo permitida a pessoas físicas e jurídicas (art. 188, $\S 1^{\circ}$ ). A partir de suas disposições, portanto, para a transferência de bens públicos por doação, o Poder Público deve atender além dos critérios previstos nas leis estaduais, as diretrizes do direito público asseguradas pela Constituição.

A Constituição do Estado do Pará, promulgada em 1989, tratou sobre a questão urbana considerando como objetivos principais o desenvolvimento das funções sociais da cidade e a

\footnotetext{
${ }^{1}$ Foi criado como uma autarquia estadual dotada de personalidade jurídica e autonomia administrativa e financeira com jurisdição em todo território estadual. Com a criação, passou a ser sua competência promover a alienação de terras, em transferências, medição, documentação, aproveitamento econômico das áreas objeto de alienação, com objetivo precípuo de a titulagem possuir clareza, exatidão e segurança.
} 
garantia do bem-estar da população, assegurando-se o direito à moradia e definindo a urbanificação e regularização como itens prioritários para recebimento de recursos de desenvolvimento urbano e social. A regularização fundiária, inclusive, teve seu uso estipulado em favor prioritariamente da população de baixa renda e de preferência sem a remoção dos moradores (art. 236, I a VII).

Tais disposições são relevantes, pois as leis estaduais anteriores não dispuseram com detalhes sobre a questão urbana. Outra novidade advinda com a Constituição Estadual constituise na permissão de alienação gratuita ou onerosa estendida a pessoas jurídicas (art. 239, IV), incluída como reflexo da Constituição Federal. Contudo ressalta-se, que embora tenha tratado sobre as formas de alienação pelo Estado, não definiu estas se aplicavam em específico a área urbana ou rural.

No âmbito Federal, a Lei $n^{\text {o }} 8.666 / 1993$ e a Lei $n^{\text {o }} 9.636 / 1998$ foram as normas que trataram mais claramente sobre a doação de bens públicos. A Lei no 8.666/1993 tornou dispensável a licitação no caso de doação permitida estritamente a outro órgão ou entidade da Administração pública em qualquer esfera de governo e dispensou licitação para alienação gratuita ou onerosa de bens imóveis, com a finalidade de serem utilizados em programas habitacionais ou de regularização fundiária de interesse social, desenvolvidos por órgãos ou entidades da Administração pública (art. $17, \mathrm{I}$, "b" e "f"), e neste contexto instituiu como limite de área para doação $250 \mathrm{~m}^{2}$.

A Lei $n^{\circ}$ 9.636/1998 reconheceu a doação de bens públicos à pessoa física e jurídica, enquanto beneficiária de programa de provisão habitacional ou de regularização fundiária de interesse social, desenvolvido por órgãos ou entidades da Administração pública. Determinou reversão ao patrimônio da União caso a finalidade da doação não seja atendida no prazo estipulado e quando cessarem as razões que justificaram a doação e quando for dado ao imóvel aplicação diversa da prevista (art. 31, I, II e III, $§ 2^{\circ}$ ), estando em consonância com as leis estaduais neste sentido.

Em âmbito estadual, coube a Lei $n^{\circ} 7.28924$ de julho de 2009 e ao Decreto estadual $n^{\circ}$ 2.135 de 26 de fevereiro de 2010, tratar sobre a regularização fundiária urbana no Estado. A Lei $n^{\circ}$ 7.289 compreendeu que poderia adquirir o domínio, o indivíduo fosse ocupante e estivesse produzindo em terras do Estado, colaborando para o cumprimento de sua função social, sendo inexigível licitação, mas mediante o pagamento do valor de terra nua, em um prazo de dez anos, com preço estipulado pelo mercado imobiliário rural, e acrescido das despesas de vistoria e das taxas de administração, na forma prevista em regulamento (art. $7^{\circ}$, caput e $\$ 1^{\circ}$ ).

O Decreto Estadual $n^{\circ} 2.135 / 2010$, que regulamentou a Lei $n^{\circ} 7.289 / 2009$ e o Decreto-Lei Estadual $\mathrm{n}^{\mathrm{o}} 57$, de 22 de agosto de 1969, tratou de forma peculiar sobre o que intitulou de regularização fundiária não onerosa, que seria uma modalidade de regularização de terras públicas através da doação, na qual seriam aferidos critérios de renda principalmente, como a declaração de que não possui outro imóvel rural e que é pobre ou de baixa renda (art. $28, \S 2^{\circ}$, I a V) e que definiu como limite para alienação não onerosa 100 (cem) hectares de terra, com a comprovação de morada permanente e cultura efetiva pelo prazo mínimo de um ano (art. 28, caput). Diferentemente das leis anteriores, vedou a concessão não onerosa de terras públicas rurais de propriedade do Estado a pessoas jurídicas, que não fosse constituída por beneficiários da reforma agrária (art. 32).

As disposições legais não indicam expressamente se se destinam a áreas urbanas ou rurais, do que se compreendeu que tratam de ambas. Deste modo, salienta-se que suas assertivas representaram um mecanismo legal no âmbito do Estado, que o direcionou para o uso das formas de alienação como meio para regularização fundiária, visando à ordenação do espaço urbano, o que se observou na regularização fundiária não onerosa, a qual se situa como doação, porém direcionada a fim específico de ordenação territorial, possibilidade não presente nas leis anteriores.

Ressalta-se que no que tange às leis estaduais do Estado do Pará foi possível verificar que as disposições legais foram evoluindo no sentido de limitar a disposição dos bens por doação, prevendo de início transferências por doação pura e simples, com plena liberalidade, para com o avanço das leis, uma doação que pode enquadrar-se como com encargos, com maiores requisitos e 
condicionantes para que o Poder Público pudesse dispor de bens a particulares, como por exemplo, a necessidade de não possuir outro terreno e o cultivo obrigatório.

Com a exposição das leis federais e estaduais sobre a doação de bens públicos, é possível compreender que seu uso sofreu modificações com o advento de novas leis sobre o tema e os critérios para disposição de imóveis pelo Poder Público acentuaram-se, partindo-se de situação de simples ocupação para critérios que contemplassem o direito social à moradia a partir do vínculo com a terra, condição socioeconômica e a ordenação territorial. Por esta razão, demonstrou-se necessária a regularização fundiária com a devida titulação dos beneficiários, situando-se como marco destas mudanças a promulgação da Constituição Federal de 1988.

A partir destas considerações, será apresentada na seção seguinte, a regulamentação legal mais recente sobre a regularização fundiária urbana em âmbito federal, que permitirá avaliar as similitudes e contrapontos com as leis expostas e seu impacto para a regularização fundiária urbana no Estado do Pará.

\section{REGULARIZAÇÃO FUNDIÁRIA URBANA E A LEI N. 13.465/2017}

A Lei n. 13.465/2017 revogou o "Capítulo III" da Lei n. 11.977/2009, que tratava da regularização fundiária de assentamentos urbanos. Esse novo marco instituiu normas gerais e procedimentos aplicáveis no território nacional na Regularização Fundiária Urbana, que chamou de "Reurb", considerando como princípios norteadores a sustentabilidade econômica, social e ambiental e a ordenação territorial, almejando a ocupação do solo de maneira eficiente e com uso funcional $\left(\operatorname{art} .9^{\circ}, \S 1^{\circ}\right)$.

A Lei n. 13.465/2017 é considerada o novo marco legal da regularização fundiária, pois em comparação a normativa anterior, desburocratizou, simplificou e agilizou os procedimentos da regularização fundiária, possibilitando o acesso à terra a população de baixa renda.

Zarelli e Aráujo Júnior (2017, p. 51) afirmam que o novo marco legal se constitui numa tentativa de trazer justiça ambiental e social, ao buscar atender os anseios de parcela da população, que por várias razões não possuíam o título de proprietário de sua moradia, independentemente do tamanho e localização, e por situações burocráticas e jurídicas não possuíam o título em seu nome.

Para isso inovou ao caracterizar o que seriam núcleos urbanos e núcleos urbanos informais, sendo os primeiros assentamentos humanos com usos e características urbanas, mesmo que situados em áreas qualificadas ou inscritas como rurais (art. $11^{\circ}, \mathrm{I}$ ), e o segundo como os clandestinos, irregulares ou nos quais não foi possível a realização da titulação de seus ocupantes, atendendo à legislação vigente a época da implantação ou regularização. Definiu ainda, como núcleo urbano informal consolidado os de difícil reversão, tendo em vista o tempo de ocupação, a natureza das edificações, a localização das vias de circulação e a presença de equipamentos públicos, além de outros aspectos a ser avaliados pelo Município (art. 11 ${ }^{\circ}$, II e III).

Para a Lei, ocupantes são aqueles que detêm área pública ou que possuam área privada, a qualquer título, de unidades imobiliárias situadas em núcleos urbanos informais (art. 11º, VIII).

A regularização terá dentre outros objetivos o de identificar núcleos urbanos informais, organizá-los e assegurar a prestação de serviços públicos a seus ocupantes, ampliar o acesso à terra urbanizada pela população de baixa renda, priorizando a permanência dos ocupantes nos núcleos informais a ser regularizados, estimular a resolução extrajudicial de conflitos, garantir o direito social a moradia digna e ordenar o pleno desenvolvimento das funções sociais da cidade (art. 10, I a XII).

Até o exposto, não houve grande mudança, mas apenas uma redefinição de conceitos e objetivos, os quais são pressupostos para as duas modalidades de regularização que a Lei estabeleceu, qual seja a regularização de interesse social - Reurb-S e a regularização de interesse específico - Reurb-E. A primeira é aplicável aos núcleos urbanos informais ocupados 
predominantemente por população baixa renda, e a segunda aos núcleos urbanos informais ocupados por população que não possua a referida característica (art. 13, I e II).

Para a Reurb-S foi garantida a isenção de custas e emolumentos para determinados atos registrais, como para o primeiro registro, para o registro da legitimação fundiária, gratuidade para o registro do projeto de regularização fundiária, com abertura da matrícula para cada unidade imobiliária urbana regularizada, para o fornecimento de certidões de registro para os atos listados, dentre outros, cabíveis sanções aos cartórios que não cumprirem tais disposições $\left(\operatorname{art} .13, \S 1^{\circ} \mathrm{I}\right.$ a VIII, e $\S 6^{\circ}$ ).

Para a regularização fundiária urbana de núcleos urbanos informais, ou a parcela deles, situados em áreas de riscos geotécnicos, de inundações ou outros riscos em lei tipificados, deverão ser realizados estudos técnicos para aferir a possibilidade de eliminação, correção ou administração do risco, e caso tais medidas não forem possíveis, o Município deverá promover a realocação dos ocupantes do núcleo urbano informal a ser regularizado. (art. 39, caput e $\S 2^{\circ}$ ).

Necessário frisar o complemento a Lei no 9.636/1998 feito pela Lei 13.465/2017 à regularização fundiária em áreas da União, estabelecendo que pessoas físicas que utilizem regularmente imóvel da União por qualquer título, até 22 de dezembro de 2016, para fins de moradia, sendo de baixa renda, e que sejam isentas do pagamento de qualquer valor pela utilização, poderão requerer diretamente ao oficial de registro de imóveis a transferência gratuita da propriedade imóvel, preenchidos os requisitos da referida Lei (art. 86).

Interessante ainda, a autorização concedida a União, suas autarquias e fundações, a transferir aos Estados, Municípios e ao Distrito Federal, áreas públicas federais ocupadas por núcleos urbanos informais, para que estes promovam a regularização (art. 90).

As disposições permitem claramente a doação de bens da União para fins de regularização fundiária, e em âmbito Estadual são importantes, pois conferem a possibilidade de promover a reordenação de áreas federais que por questão de competência e domínio do ente federado, podem estar sem a devida regularização, constituindo-se a doação como um instrumento possível neste processo.

No que tange aos legitimados para requerer a regularização, a Lei n ${ }^{\circ}$ 13. 465/2017 ratificou assertivas da Lei $n^{\circ} 9.636 / 1998$, atribuindo a possibilidade de requerê-la aos Entes federados por meio de entidades da administração pública direta e indireta, mas também aos próprios beneficiários, individual ou coletivamente, diretamente ou por meio de cooperativas habitacionais, associações de moradores, fundações, organizações sociais, organizações da sociedade civil de interesse público ou outras associações civis que tenham por fim a regularização fundiária urbana. São legitimados ainda proprietários, loteadores ou incorporadores, a Defensoria Pública em nome dos beneficiários hipossuficientes e o Ministério Público (art. 14, I a V).

A Lei ressalva, entretanto, que se os proprietários, loteadores ou incorporadores derem causa a formação dos núcleos urbanos informais, para depois requerer a regularização, poderão ser

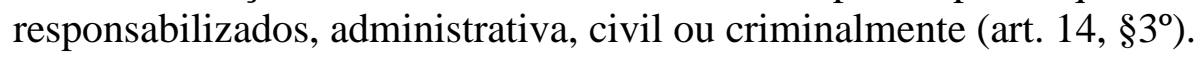

Uma especificidade advinda da Lei foi a previsão da legitimação fundiária, não presente nas disposições anteriores, instituída como uma nova forma de registrar a propriedade. É definida como forma originária de aquisição de direito real de propriedade conferido por ato do Poder Público aquele que detiver área pública ou possuir área privada, que constitua unidade imobiliária com destinação urbana integrante de núcleo urbano informal consolidado existente em 22 de dezembro de 2016 (art. 23, caput).

Nesta, o beneficiário adquire a unidade imobiliária com destinação urbana devidamente regularizada, livre e sem ônus, gravames ou inscrições em sua matrícula de origem, exceto quando disserem respeito ao próprio legitimado (art. $23, \S 2^{\circ}$ ).

$\mathrm{Na}$ Reurb-S, definiu-se para concessão de legitimação fundiária critérios com semelhanças às leis anteriores, como a proibição de ser concessionário, foreiro ou proprietário de imóvel urbano ou rural, restringindo que o indivíduo não tenha sido beneficiado por mais de uma 
legitimação fundiária ou de posse de imóvel urbano com mesma finalidade, ainda que situado em núcleo urbano distinto. Tratando-se de imóvel urbano com finalidade não residencial, deve ser reconhecido o interesse social de sua ocupação pelo Poder Público (art. 23, $1^{\circ}$, I a III).

Nesta forma de regularização, os entes federados e suas entidades vinculadas quando titulares do domínio estão autorizados a conceder o direito de propriedade aos ocupantes do núcleo urbano informal regularizado por meio da legitimação fundiária e para isso, deverão encaminhar a Certidão de Regularização Fundiária - CRF para registro imediato da aquisição de propriedade, consistindo em ato administrativo de aprovação da regularização fundiária (art. 41, caput). Neste caso, estarão dispensadas a apresentação de título individualizado e as cópias da documentação referente à qualificação do beneficiário, o projeto de regularização fundiária aprovado, a listagem dos ocupantes e sua devida qualificação e a identificação das áreas que ocupam. (art. $23, \S \S 4^{\circ}$ e $5^{\circ}$ ).

Além disso, para garantir que os ocupantes que não participaram deste processo no início, mas se enquadram nos requisitos da Reurb-S possam ser adquirir tal direito, a Lei previu a possibilidade de o Poder Público atribuir domínio adquirido por legitimação fundiária aos ocupantes que não tenham constado da listagem inicial, mediante cadastramento complementar, sem prejuízo a nenhum direito que tenha sido garantido aos demais (art. 23, § $6^{\circ}$ ).

Este é um dos aspectos que atribuirá celeridade ao processo de regularização, na medida em que a própria Administração pública concederá o direito de propriedade aos ocupantes, inclusive de forma coletiva, cabendo ao registro o aspecto formal.

No processo administrativo para regularização, definiu-se que compete ao Município em que esteja situado o núcleo urbano informal classificar as modalidades de regularização, processar, analisar e aprovar os projetos de regularização fundiária e emitir a CRF, e quando a Reurb for requerida pela União ou pelos Estados, esta classificação será sua responsabilidade (art. 30, I a III, $\left.\S 1^{\circ}\right)$.

Após a instauração da Reurb, o Município deverá buscar determinar a titularidade do domínio dos imóveis onde está situado o núcleo urbano informal a ser regularizado, e notificar os titulares de domínio, os responsáveis pela implantação do núcleo urbano informal os confinantes e os terceiros eventualmente interessados, para que se desejem, apresentem impugnação no prazo de 30 (trinta) dias, e existindo impugnação, deverá ser iniciado procedimento extrajudicial de composição de conflitos (art. $31, \S \S 1^{\circ}$ a $3^{\circ}$ ).

Conforme a Lei, o projeto de regularização fundiária deve indicar no mínimo a planta do perímetro do núcleo urbano informal, projeto urbanístico, memoriais descritivos, estudo técnico ambiental, cronograma físico de serviços e implantação de obras de infraestrutura essencial, deverá considerar as características da ocupação e da área ocupada para definir parâmetros urbanísticos e ambientais específicos, dentre outras exigências (art. 35, I a X e $\S$ único).

Ressaltasse a pontual distinção feita pela Lei no que tange a responsabilização pelo custeio da regularização, pois na Reurb-S sua elaboração e custeio cabe ao ente público, Município ou Distrito Federal se operada sobre área de titularidade de ente público, e se operada sobre área titulada por particular, a quem caberá implementar a infraestrutura essencial quando necessária (art. 33, I, “a” e "b").

Na Reurb-E a regularização fundiária será contratada e custeada por seus potenciais beneficiários ou requerentes privados, e quando incidir sobre áreas públicas, caso exista interesse público, o Município poderá proceder à elaboração e custeio do projeto de regularização fundiária e implantação da infraestrutura essencial, cobrando posteriormente seus beneficiários (art. 33, II e III).

Na Reurb-S caberá ao Poder Público diretamente ou por meio da Administração indireta, implementar a infraestrutura essencial, os equipamentos comunitários e as melhorias habitacionais previstos nos projetos de regularização e arcar com os ônus de sua manutenção, enquanto que na Reurb-E o Distrito Federal ou os Municípios definirão, conforme a aprovação dos projetos de regularização fundiária, os responsáveis pela implantação da infraestrutura essencial e dos 
equipamentos públicos ou comunitários, e a implementação das medidas de mitigação e compensação urbanística e ambiental e dos estudos técnicos, podendo a responsabilidade ser transferida aos próprios beneficiários (art. 37 e 38, I a III).

Uma inovação para o processo de regularização fundiária trata-se da possibilidade de câmaras de prevenção e resolução administrativa de conflitos, com competência para solucionar conflitos relacionados à Reurb, mediante solução consensual e passível celebração de ajustes com os Tribunais de Justiça Estaduais e ainda, promoção de mediação coletiva de conflitos (art. 38, I a III e $\S 1^{\circ}$ ).

De modo prático, tem-se que a Regularização fundiária urbana passou a ter sete fases: o requerimento dos legitimados; processamento administrativo do requerimento com prazo para manifestação dos proprietários ou terceiros interessados; elaboração do projeto da Reurb; saneamento do processo administrativo; decisão da autoridade competente; expedição da CRF pelo Município; registro da CRF pelos Legitimados perante o Oficial do cartório do registro de imóveis (art. 28, I a VII). Para efetiva implantação das medidas da Reurb os entes federativos poderão celebrar convênios ou outros instrumentos com o Ministério das Cidades (art. 29).

Para fins de regularização fundiária urbana, a Lei n. 13.465/2017 descreveu instrumentos que podem ser empregados no âmbito da regularização fundiária, sem, contudo, excluir outros institutos jurídicos cabíveis, dois quais se destacam a legitimação fundiária, a concessão de uso especial para fins de moradia, a concessão de direito real de uso, a compra e venda e a própria doação, como forma cabível para implementar a Reurb (art. 15, I a XV). Trata-se, pois de um rol exemplificativo, com margem para a atuação discricionária do Poder Público em escolher o meio jurídico para promover a regularização fundiária urbana.

A partir das considerações apresentadas é importante pontuar as possíveis distinções da Lei n. 13.465/2017 em comparação à Lei n. 11.977/2009, legislação anterior em âmbito federal sobre a regularização fundiária urbana.

A Lei n. 11.977/2009 também definia duas modalidades de regularização, a de interesse específico e de interesse social. Para ambas, a elaboração de um projeto de regularização fundiária era requisito basilar, que no caso da regularização de interesse social precisava ser aprovado pelo Município (art. 53).

Na Lei n. 11.977/2009, a regularização fundiária de interesse social poderia ser feita em assentamentos irregulares ocupados por população de baixa renda, mas com o requisito temporal de que a área estivesse ocupada, de forma mansa e pacífica, há, no mínimo, 5 (cinco) anos, que se tratasse de imóveis situados em ZEIS ${ }^{2}$, ou ainda nos casos de áreas da União, dos Estados, do Distrito Federal e dos Municípios declaradas de interesse para implantação de projetos de regularização fundiária de interesse social (art. 47, VII e VIII). A regularização fundiária de interesse específico seria aplicável a assentamentos que não se enquadrassem nestes critérios.

A Lei $n^{\circ} 13.465 / 2017$ por sua vez, resumiu a aplicação da Reurb-S a núcleos urbanos informais ocupados por população de baixa renda, não prevendo mais o critério temporal de ocupação como na legislação anterior, mas apenas estipulou possíveis sanções aqueles que derem causa a formação de núcleos urbanos informais para depois requerer a regularização. Alterou também a disciplina sobre as Zonas Especiais de Interesse Social (ZEIS), que de uma das hipóteses para regularização fundiária de interesse social, se tornou na Lei n. 13. 465/2017, instrumento de planejamento urbano ao qual a regularização fundiária não esta condicionada (art. 18, caput e $\S 2^{\circ}$ ).

No que tange aos legitimados para promovê-la a Lei n. 11.977/2009 trazia possibilidade aos entes federados e a população moradora de forma individual ou em grupo, por intermédio de cooperativas, associações e organizações sociais que possuíssem por escopo a promoção de atividades ligadas ao desenvolvimento urbano ou à regularização fundiária (art. 50, I e II). As

\footnotetext{
${ }^{2}$ Zona Especial de Interesse Social, que segundo a Lei n. 11.977 tratava-se de parcela de área urbana instituída pelo Plano Diretor ou definida por outra lei municipal, destinada predominantemente à moradia de população de baixa renda e sujeita a regras específicas de parcelamento, uso e ocupação do solo (Art. 47, V).
}

Revista de Direito Brasileira | São Paulo, SP | v. 21 | n. 8 | p. 62-83 |Set./Dez. 2018 
disposições foram contempladas pela Lei 13.465/2017, mas incluiu-se expressamente a possibilidade de ser requerida pelos proprietários, loteadores e incorporadores, e ainda conferiu legitimidade ao Ministério Público e a Defensoria Pública em favor dos beneficiários hipossuficientes.

No que tange a responsabilidade pela infraestrutura no âmbito da regularização fundiária conforme Lei n. 11.977/2009, na modalidade interesse social caberia ao Poder Público, diretamente ou por meio de seus concessionários ou permissionários de serviços públicos o ônus (art. 55), enquanto que na de interesse específico a responsabilidade por esta implementação poderia ser compartilhada com os beneficiários da regularização fundiária de interesse específico, mas seria preciso analisar os investimentos em infraestrutura e equipamentos comunitários já realizados pelos moradores, e o poder aquisitivo da população a ser beneficiada (art. 62 , I a IV e $\S 1^{\circ}$, I e II).

Na Lei n. 13.465/2017, a responsabilidade na Reurb-S pertence também ao Poder Público, contudo na Reurb-E a Lei suspendeu os critérios existentes na Lei anterior para transferir a responsabilização aos beneficiários, estipulando sua responsabilidade como regra nesta modalidade de regularização, podendo o Poder Público promovê-la apenas se for de seu interesse por incidir em área pública, com previsão expressa de cobrança futura dos beneficiários pela implementação.

Contrapondo as legislações, observa-se que a Lei n. 13.465/2017 almejou a simplificação de conceitos e procedimentos para a regularização fundiária urbana, redefinindo instrumentos já presentes na norma anterior, o que se percebe desde logo com a definição dos núcleos urbanos informais a partir das características urbanas, considerando a ausência de titulação e as características da área ocupada. Neste viés, a legitimação fundiária apresenta-se como a mudança mais relevante da nova legislação, que no âmbito da Reurb-S permite a aquisição originária do direito real de propriedade nos núcleos urbanos informais consolidados.

Em âmbito local, compreende-se que a edição da Lei n. 13.465/2017 contribuirá para orientação do Estado do Pará ao promover a regularização fundiária, pois as definições que estabeleceu para área urbana permitem melhor adequação da área destinada a regularização fundiária, na medida em que o conceito de núcleo urbano informal passou a ter grande alcance, podendo inclusive ser situado em área rural.

Diferente das legislações anteriores, a Lei 13.465/2017 elencou um rol de institutos jurídicos que podem ser empregados como instrumentos da regularização fundiária, com previsão expressa para a doação (art. 15, XIV), e não excluiu nenhuma especificamente do rol de possibilidades do Poder Público ao promover a regularização fundiária, em vez disso, conferiu discricionariedade ao Poder Público para que eleja melhor forma para atender a necessidade social existente.

Desta forma, compreende-se que as disposições estaduais não se confrontam totalmente com o que instituiu a Lei 13.465/2017 no que se refere a regularização fundiária urbana, e sendo assim para que o Estado do Pará atue neste âmbito poderá utilizar-se da regulamentação legal que possui, compatibilizando-a com o que institui a referida Lei, principalmente na especificação da área urbana a ser regularizada e na forma e processo para legitimação.

Ilustra-se isso quando se demonstra, por exemplo, a regularização fundiária não onerosa prevista no Decreto Estadual $n^{\circ}$ 2.135/2010, que pelos seus requisitos pode enquadrar-se como uma Reurb-S, prevista na Lei n. 13.465/2017, que assim como na previsão estadual, requer prioritariamente que o beneficiário seja baixa renda e não possua outro imóvel urbano ou rural, partindo do pressuposto que a doação é um instrumento jurídico para promover a para a regularização fundiária urbana.

Considerando as proposições apresentadas, compreende-se que a Lei n. 13.465/2017 buscou simplificar o processo de regularização fundiária urbana, reduzindo conceitos e etapas presentes na legislação anterior e considerando os núcleos urbanos informais a partir de caracteres mais concretos, correspondentes com a realidade das cidades. 
Neste contexto, a nova lei será de grande valia como orientação ao desenvolvimento urbano dos Municípios do país e em especial aos situados na região amazônica, tendo em vista o processo de urbanização e crescimento desordenado vivenciado, que perecem de organização e condições urbanísticas e ambientais adequadas ao bem-estar da população.

Outrossim, em consonância com o que destacam Zarelli e Araújo Júnior (2017, p. 52) é necessário que a regularização fundiária urbana promova não apenas a titulação da posse do beneficiário, mas também garanta o acesso da população a serviços públicos de qualidade como saúde, educação, segurança, transporte e ainda, proporcione empregos nas proximidades dos núcleos urbanos, a fim de assegurar condições dignas de vida a população, além de proteger o meio ambiente.

Assim, é de grande importância uma base legal que considere as necessidades de organização do espaço propriamente urbano, com aspectos e necessidades específicas, destacados do meio rural, o que poderá ser observado nas peculiaridades do Estudo de caso do Município de Belém, a seguir analisado.

\section{ATUAÇÃO ESTADUAL EM REGULARIZAÇÃO FUNDIÁRIA URBANA: ESTUDO DE CASO DO MUNICÍPIO DE BELÉM}

O Município de Belém foi criado em 12 de janeiro de 1616 e está localizado ao nordeste do Estado a $120 \mathrm{~km}$ do mar e $160 \mathrm{~km}$ da linha do equador, e possui aproximadamente 1.059,458 $\mathrm{km}^{2}$ de área territorial (IBGE, 2017).

Segundo dados do IBGE (2018), o Município possui população estimada de 1.485 .732 de habitantes. A cidade de Belém é a capital do Estado do Pará.

A partir da realização do levantamento documental dos títulos de doações concedidos pelo Estado para particulares no Município de Belém, foi feita a sistematização dos dados em planilha, identificando os seguintes dados: número do título; cadastro; data da concessão; processo de origem; nome do beneficiário do título; limites e confrontações; dimensão da área doada; e espaço para possíveis observações. Para o estudo de caso foram analisados apenas os dados dos títulos concedidos no Município de Belém.

O levantamento documental dos títulos de doação foi feito a partir de imagens obtidas no Instituto das Terras do Pará (ITERPA). Foram selecionados dez livros de doação, sob os números 22, 23, 24, 25, 26, 76, 97, 62, 92 e 98, nos quais haviam títulos datados entre 1992 a 2002, e feita sistematização em planilha das informações de doações contidas nos títulos.

$\mathrm{Na}$ análise constatou-se que foram expedidos 437 (quatrocentos e trinta e sete) títulos a particulares pelo Estado do Pará no Município de Belém. A maior parte dos títulos de doação, cerca de 99,54\%, foi expedida na área urbana do Município de Belém no ano de 2002, em área denominada "Loteamento Tropical Pratinha", dos quais alguns foram retificados e passaram a ser denominados apenas "Pratinha II".

As demais áreas eram concessões mais antigas com data de 1992 e 1998, as quais foram descritas como zona rural do município de Belém. Estas foram registradas como "Sitio Caju" e "Colônia Pinheiro".

Do total de títulos, $59,04 \%$ foi destinado a mulheres, $40,73 \%$ a homens e $0,23 \%$ a pessoa jurídica. Observou-se ainda, que do total considerado, foram cancelados 37 (trinta e sete) títulos, nos anos de 2008 e 2010.

As áreas doadas na zona urbana de Belém eram pequenas, se comparado ao limite previsto nas Leis estaduais vigentes até o ano da expedição dos títulos, o qual era de 100 (cem) hectares. As áreas da zona rural também possuíam dimensões inferiores a este limite.

Constatou-se ainda que 60 (sessenta) títulos foram retificados, principalmente nos anos de 2008 e 2010, no que concerne a profissão dos beneficiários, ao nome da localidade, aos limites e 
confrontações e a área do imóvel, alterando-se o nome das ruas para lotes com numeração, assim como alterações na medida da área de "ares" para "metros quadrados".

\section{QUADRO 1 - Doações realizadas pelo Estado do Pará no Município de Belém}

\begin{tabular}{|c|c|c|}
\hline \multicolumn{2}{|c|}{ Dados Coletados } & Percentual (\%) \\
\hline \multirow{3}{*}{ Beneficiários } & Mulheres & $59,04 \%$ \\
\cline { 2 - 3 } & Homens & $40,73 \%$ \\
\cline { 2 - 3 } & Pessoa Jurídica & $0,23 \%$ \\
\hline \multicolumn{2}{|c|}{ Doações na área urbana } & $99,54 \%$ \\
\hline \multicolumn{2}{|c|}{ Áreas de até 100 (cem) hectares } & $100 \%$ \\
\hline
\end{tabular}

Fonte: elaborado pela autora (2017)

A exposição dos dados permite interpretar que a quase totalidade dos títulos analisados foram provenientes de doações na área urbana do Município de Belém, e mais da metade destinados a mulheres, com áreas inferiores aos limites das Leis estaduais vigentes no período em que foram realizadas as doações.

Com a realização da análise quantitativa dos títulos, foi possível identificar um diagnóstico geral sobre as doações realizadas pelo Estado do Pará, de modo que possuiu por finalidade formar compreensão acerca da correspondência das doações com a legislação estadual e federal apresentadas, considerando se foram constituídas em total ou parcial observância destas.

$\mathrm{Na}$ análise qualitativa se observaram as transferências feitas em área descrita como zona rural de Belém, embora mais antigas, possuíam as mesmas características das transferidas na zona urbana, isto é, foram destinadas a pessoas físicas e com áreas inferiores ao limite estadual. As áreas designadas como rurais, possuíam localidade distinta, não havendo ligação específica entre as concessões.

Constatou-se que as doações foram fundamentadas na Constituição Federal de 1988, na Constituição estadual de 1989 e no Decreto estadual $n^{\circ}$ 7.454/1971, observadas ainda, as disposições federais sobre a doação, no que tange a reversão do imóvel ao patrimônio do Estado quando descumpridas as leis fiscais, tributárias e ambientais.

Entendeu-se que as doações analisadas nos títulos emitidos pelo Estado do Pará no ano de 2002, na área urbana de Belém, possuíam característica de um processo de regularização fundiária, o que se justifica na medida em que foram transferidas por meio de doação, áreas em larga escala e a vários beneficiários, visando conceder títulos àqueles que residiam na localidade.

Entretanto, por se tratar da zona urbana do Município, considera-se que havia um entrave legal a este processo, na medida em que não existia até a data de expedição dos títulos uma lei específica que regulamentasse a regularização fundiária direcionada a área urbana.

As Leis estaduais até a expedição destes títulos permitiam a doação a particular por um critério de ocupação, para aqueles que tivessem morada habitual e cultura efetiva, que não possuíssem outro imóvel, delimitando até 100 hectares para a doação, como na Lei estadual $\mathrm{n}^{\circ}$ 3.641/1966 e o Decreto estadual no 7.454/1971.

Contudo, esta previsão legal era direcionada a transferência por doação em caráter individual, destinado a indivíduos que a requeressem e que para isso preenchessem os requisitos previstos em Lei.

As doações analisadas nos títulos, poderiam se enquadrar nesta hipótese, mas se materializaram como um ato do Poder Público realizado em larga escala, visando beneficiar grande número de indivíduos com a titulação e ordenar o território urbano, o que é parte integrante e precípua de um processo de regularização fundiária. 
Os títulos foram concedidos com base no Decreto $n^{\circ} 7.454 / 1971$, fundamentação que se compreendeu como tecnicamente inadequada. Porém, seu uso derivou da inexistência naquele momento de Lei estadual específica para legitimar um processo de regularização fundiária, considerando o caráter e finalidade destas doações. Em contrapartida, para as doações nas áreas denominadas zona rural do Município, este foi o instrumento legal correto para a expedição dos títulos, visto que foram concessões isoladas a pessoas físicas, sem maiores peculiaridades.

Neste sentido, observou-se que os títulos apresentavam a peculiaridade de que todos os beneficiários das doações foram registrados com a profissão de agricultores, mesmo tratando-se de concessões no perímetro urbano de Belém. Nos anos de 2008 e 2010, exatamente 60 (sessenta) títulos foram retificados, alterando-se a profissão dos beneficiários para atividades bastante diversas, como músico, comerciante, cabelereiro, costureira, eletricista, dentre outras ocupações.

Buscando elucidar as razões da caracterização de todos os beneficiários como agricultores, observou-se que os títulos traziam como fundamento da doação o art. $241 \S \S 1^{\circ}$, $2^{\circ}$ e $3^{\circ}$ da Constituição Estadual de 1989.

O $\S 1^{\circ}$ incisos I a IV do art. 241 tratava em linhas gerais que a concessão de terras públicas seria feita por contrato, com cláusulas que dispusessem sobre a exploração da terra em conformidade com a política agrícola e agrária e seus respectivos planos e programas, em consonância com a Constituição Federal art. 188, cláusulas com a proibição de o concessionário possuir de outro imóvel rural, da obrigação de residência permanente dos beneficiários na localidade em que se situava a área de objeto do contrato, manutenção das reservas florestais obrigatórias e observância das restrições do uso do imóvel.

O $\S 2^{\circ}$ do art. 241, tratava da rescisão do contrato de concessão em caso de descumprimento de suas cláusulas e por fim o $\$ 3^{\circ}$ dispunha que o Estado poderia executar sem ônus aos concessionários, a regularização fundiária das terras públicas, quando se tratassem de trabalhadores rurais que residissem na terra e a cultivassem com a força de trabalho da própria família, estando caracterizados com baixa renda. Estes dispositivos foram revogados na Emenda Constitucional nº 48 de 8 de junho de 2011, publicada no Diário Oficial de 15 de junho de 2011.

Compreende-se que a caracterização de todos os beneficiários como agricultores, ocorreu no intuito de enquadra-los legalmente nestas disposições da Constituição Estadual de 1989, especialmente no art. $241 \S 3^{\circ}$, a partir do qual se considerava cabível a transferência de áreas a trabalhadores rurais como parte do processo de regularização fundiária de terras públicas, embora se tratasse de uma regulamentação para a área rural, sendo inadequado seu uso para zona urbana do município de Belém.

Havia deste modo, uma lacuna quanto à regulamentação legal da regularização fundiária por doação na área urbana, pois existiam leis estaduais que tratavam a doação de bens imóveis a particulares, porém não incorporavam esta possibilidade, e a Constituição Estadual de 1989 a previa, mas apenas quando destinada a trabalhadores rurais.

Necessário pontuar a doação à pessoa jurídica entre os títulos expedidos em 2002, no Loteamento Tropical Pratinha II. Tratava-se apenas, de uma igreja denominada igreja Pentecostal Deus e Amor, a qual recebeu área de tamanho semelhante ao das demais concessões, no limite previsto da legislação Estadual.

A transferência por alienação gratuita à pessoa jurídica foi permitida na Constituição Estadual de 1989, mas em termos de Lei estadual, também não havia até a data de expedição dos títulos previsão legal de doação para estas.

Além disso, houve vício de motivação nesta transferência, pois conforme analisado na revisão bibliográfica, a doação a entidades religiosas requer a existência de interesse público devidamente motivado, em observância sobretudo ao princípio da laicidade e legalidade, o que não ocorreu no caso concreto, pois a doação efetuou-se com plena liberalidade e nos mesmos moldes das demais transferências a beneficiários individuais. 
Apenas em 2009, com o Decreto estadual no 2.135/2010 o Estado do Pará obteve nova regulamentação que tratou claramente da regularização fundiária, com cumprimento de requisitos específicos e imposição a pessoa jurídica de receber a doação desde que inserida em processo de regularização fundiária. Entende-se que esta seria a regulamentação legal adequada para este processo de doação analisado com títulos expedidos em 2002.

A partir da análise dos títulos evidenciou-se que alguns possuíam contrariedades frente à legislação federal, no que concerne à área máxima permitida ao Poder Público em transferências por doação prevista na Lei federal n 8.666/1993 no art. 17 alínea "h", a qual é de $250 \mathrm{~m}^{2}$ na condição de que esteja inserida em programas de regularização fundiária de interesse social. Verificou-se que determinados títulos possuíam área bastante superior a este limite, como por exemplo, os presentes nas folhas $n^{\circ} 49,50$ e 134 do livro 24 .

Na legislação federal considera-se a condição socioeconômica como pressuposto para receber um bem imóvel público, o que pode ser uma contrariedade frente à expedição dos títulos analisados, já que nas Leis estaduais não se exigia ser baixa renda como um requisito para receber doação, compreensão independente da análise feita acima sobre o uso dos dispositivos da Constituição Estadual de 1989.

Considerando o que foi apresentado, compreendeu-se que as doações realizadas pelo Estado verificadas nos títulos seguiram em parte a legislação estadual vigente no tempo de sua expedição, isto porque houve a observância com base em seus termos dos requisitos para os beneficiários receberem doação, como a morada habitual e cultura efetiva e a proibição de possuir outro imóvel.

Contudo, analisando o processo por completo, restou claro que a justificação legal para a expedição dos títulos foi inadequada, na medida em que o intuito do Poder Público foi promover a ordenação territorial através do beneficiamento de muitas pessoas por doação em determinada localidade, fim para o qual na área urbana não se tinha instrumento legal específico.

Destaca-se que as doações realizadas pelo Estado na área urbana do Município de Belém incidiram de forma determinante na localidade do Município onde ocorreram as concessões, na medida em que possuíram grande representatividade na definição da região devido à pluralidade de doações.

Percebe-se que a atribuição dos títulos foi motivada pela necessidade de estruturação desta parcela do território do Município, mas orientou-se sem o devido enfrentamento da questão de ausência de regulamentação legal específica para o processo de doação em zona urbana, que permitisse a titulação por via legal correta para que fossem reconhecidos para aos beneficiários amplos direitos de cidadania que um processo de regularização fundiária urbana permite como se observa nas regulamentações atuais.

\section{CONCLUSÃO}

A doação de bens imóveis públicos é uma forma de alienação presente no contexto de formação do Brasil, reconhecida pela doutrina e permitida como ato legítimo dos entes públicos, para receber e efetuar doações de bens imóveis a particulares, desde que observada a legislação civil e administrativa. As leis estaduais e federais preveem a doação gratuita e onerosa como formas passíveis de uso pelo Poder Público, as quais são escolhidas a partir do objetivo pretendido por este.

Delineou-se uma tendência nacional, iniciada com a Lei Federal $n^{\circ}$ 9.636/1998, em reconhecer a importância da regularização fundiária como um direito social, isto é, como pressuposto para a garantia de outros direitos básicos, e que deve estar associada a garantia ao meio ambiente ecologicamente equilibrado. Para isso, a doação é claramente uma das formas possíveis que permitem ao Poder Público transferir um bem público e ao mesmo tempo cumprir uma função 
social, e atualmente está expressamente prevista na Lei n. 13.465/2017 como instrumento para a regularização fundiária urbana.

Na prática evidenciou-se contrariedade à hipótese inicial da pesquisa, tendo em vista que o estudo aprofundado do tema, no que concerne a doutrina e legislação específica em âmbito estadual e federal, revelou que a doação de bens públicos além de possuir vasta presença nas leis analisadas, se consolidou no decorrer dos anos como forma de alienação gratuita de bens públicos e instrumento para regularização fundiária. Embora tradicionalmente o regramento do instrumento provenha do direito privado, diversas normas do direito administrativo estabeleceram limites à disposição dos bens públicos, instituindo critérios e finalidades que os beneficiários deveriam possuir para recebê-la.

No Estado do Pará compreendeu-se que as leis originalmente possuíam menor rigidez no que tange à disposição dos bens públicos. Tal característica ainda pode ser percebida mesmo após 2009, na legislação em vigor sobre regularização fundiária, uma vez que os critérios para alienação gratuita permanecem genéricos, principalmente no que tange ao limite de área permitida para doação.

O estudo de caso demonstrou que as transferências por doação no Estado derivaram do objetivo do Poder Público de promover programas de regularização fundiária e não numa distribuição avulsa de títulos de doação impulsionada por demanda espontânea. Todavia, a ausência de legislação específica para fundamentar a regularização fundiária urbana utilizando a doação como instrumento fez com que a fundamentação legal das transferências fosse inadequada.

Observa-se que a Lei n. 13.465/2017 enquanto norma geral de direito urbanístico, buscou contemplar soluções de ordenação do território urbano para os diferentes entes federados. Nesse sentido, a nova Lei tem impacto positivo para o Estado do Pará, uma vez que permitirá uma destinação patrimonial em áreas urbanas sem vícios formais para a titulação de projetos de regularização fundiária urbana.

A despeito das inadequações identificadas no estudo de caso, no que se refere ao embasamento legal da titulação, as doações analisadas possuíram impacto relevante no contexto urbano do Município, uma vez que número elevado de famílias teve acesso a propriedade, que é um dos meios de garantia do direito fundamental à moradia.

Portanto, a doação de bens imóveis públicos para fins urbanísticos, necessita de maiores debates e estudos, pois como se vislumbrou na área urbana do Município de Belém, é uma forma lícita e usada em larga escala pelo Poder Público no intuito de ordenar o território, fazendo-se necessário um olhar mais atento ao seu uso para fins de regularização fundiária urbana.

\section{REFERÊNCIAS}

BRASIL. Constituição de 1988. Constituição da República Federativa do Brasil: promulgada em 5 de outubro de 1988. Organização do texto: Luiz Roberto Curia, Lívia Céspedes e Juliana Nicoletti. 11 ed. São Paulo: Saraiva, 2014.

BRASIL. Código civil de 2002. Código Civil de 2002: promulgado em 10 de janeiro de 2002. Organização do texto: Luiz Roberto Curia, Lívia Céspedes e Juliana Nicoletti. 11 ed. São Paulo: Saraiva, 2014.

BRASIL. Lei n. 8.666, de 21 de junho de 1993. Regulamenta o art. 37, inciso XXI, da Constituição Federal, institui normas para licitações e contratos da administração pública e dá outras providências. Diário Oficial da União, Brasília, DF, v. 6, p. 8269, 21 jun., 1993. Seção 1.

BRASIL. Lei n. 9.636, de 15 de maio de 1998. Dispõe sobre a regularização, administração, aforamento e alienação de bens imóveis de domínio da União, altera dispositivos dos Decretos- 
Leis $\mathrm{n}^{\circ} \mathrm{s} 9.760$, de 5 de setembro de 1946, e 2.398, de 21 de dezembro de 1987, regulamenta o $\S$ $2^{\circ}$ do art. 49 do Ato das Disposições Constitucionais Transitórias, e dá outras providências. Diário Oficial da União, Brasília, DF, v. 5, p. 2, 18 mai., 1998. Seção 1.

BRASIL. Lei n. 11.977 de 07 de julho de 2009. Dispõe sobre o Programa Minha Casa, Minha Vida - PMCMV e a regularização fundiária de assentamentos localizados em áreas urbanas; altera o Decreto-Lei no 3.365, de 21 de junho de 1941, as Leis nos 4.380, de 21 de agosto de 1964, 6.015, de 31 de dezembro de 1973, 8.036, de 11 de maio de 1990, e 10.257, de 10 de julho de 2001, e a Medida Provisória no 2.197-43, de 24 de agosto de 2001; e dá outras providências. Diário Oficial da União, Brasília, DF, p. 2, 08 jul., 2009. Seção 1.

BRASIL. Lei. 13.465 de 11 de julho de 2017. Dispõe sobre a regularização fundiária rural e urbana, sobre a liquidação de créditos concedidos aos assentados da reforma agrária e sobre a regularização fundiária no âmbito da Amazônia Legal; institui mecanismos para aprimorar a eficiência dos procedimentos de alienação de imóveis da União; altera as Leis nos 8.629, de 25 de fevereiro de 1993, 13.001, de 20 de junho de 2014, 11.952, de 25 de junho de 2009, 13.340, de 28 de setembro de 2016, 8.666, de 21 de junho de 1993, 6.015, de 31 de dezembro de 1973, 12.512, de 14 de outubro de 2011, 10.406, de 10 de janeiro de 2002 (Código Civil), 13.105, de 16 de março de 2015 (Código de Processo Civil), 11.977, de 7 de julho de 2009, 9.514, de 20 de novembro de 1997, 11.124, de 16 de junho de 2005, 6.766, de 19 de dezembro de 1979, 10.257, de 10 de julho de 2001, 12.651, de 25 de maio de 2012, 13.240, de 30 de dezembro de 2015, 9.636, de 15 de maio de 1998, 8.036, de 11 de maio de 1990, 13.139, de 26 de junho de 2015, 11.483, de 31 de maio de 2007, e a 12.712, de 30 de agosto de 2012, a Medida Provisória no 2.220, de 4 de setembro de 2001, e os Decretos-Leis nos 2.398, de 21 de dezembro de 1987, 1.876, de 15 de julho de 1981, 9.760, de 5 de setembro de 1946, e 3.365, de 21 de junho de 1941; revoga dispositivos da Lei Complementar no 76, de 6 de julho de 1993, e da Lei no 13.347, de 10 de outubro de 2016; e dá outras providências. Diário Oficial da União, Brasília, DF, p. 1, 12 jul., 2017. Seção 1.

CARVALHO FILHO, José dos Santos. Manual de direito administrativo. 27 ed. rev., ampl. e atual. São Paulo: Atlas, 2014.

DI PIETRO, Maria Sylvia Zanella. Direito Administrativo. 27 ed. São Paulo: Atlas, 2014.

FARIAS, Cristiano Chaves de; ROSENVALD, Nelson. Curso de direito civil: teoria geral e contratos em espécie. vol. 4, 5 ed. São Paulo: Atlas, 2015.

GARCIA, Flávio Amaral. Licitações e contratos administrativos: casos e polêmicas. Rio de Janeiro: Lumen Juris, 2009.

GASPARINI, Diógenes. Direito Administrativo. 8. ed. rev. e atual. São Paulo: Saraiva, 2003.

GOMES, Orlando. Contratos. 26. Ed. Rio de Janeiro: Forense, 2009.

GONÇALVES, Carlos Roberto. Direito civil brasileiro: contratos e atos unilaterais. v.3,9 ed. São Paulo: Saraiva, 2012.

IBGE - Instituto Brasileiro de Geografia e estatística. Belém: área da unidade territorial. Disponível em: https://cidades.ibge.gov.br/brasil/pa/belem/panorama. Acesso em 10 jun.2017. 
IBGE - Instituto Brasileiro de Geografia e estatística. Belém: população estimada. Disponível em: http://cidades.ibge.gov.br. Acesso em: 20 out. 2018.

MARRARA, Thiago. Bens públicos: domínio urbano: infra-estruturas. Belo Horizonte: Fórum, 2007.

MARQUES NETO, Floriano de Azevedo Marques. Bens Públicos: função social e exploração econômica. O regime jurídico das utilidades públicas. Belo Horizonte: Fórum, 2009.

MARCONI, Marina de Andrade; LAKATOS, Eva Maria. Fundamentos de metodologia científica. 7 ed. São Paulo: Atlas, 2010.

MUNIZ, Joao de Palma. Índice geral dos registros de terras. Primeiro tomo. Belém: Imprensa Official, 1907.

PARÁ. Decreto n. 410, de 8 de outubro de 1891. Regula a alienação de terras devolutas situadas dentro dos limites do Estado do Pará, e dá regras para a revalidação de sesmarias e outras concessões do governo e para a legitimação das posses mansas e pacíficas. Diário Oficial do Estado do Pará, Belém, 10 de out., 1891.

PARÁ. Lei n. 824, de 14 de outubro de 1902. Autoriza o governo a conceder títulos definitivos de propriedade sem indenização alguma aos atuais ocupantes de diversos núcleos coloniais. Diário Oficial do Estado do Pará, Belém, 15 de out., 1902.

PARÁ. Lei n. 1.423, de 9 de outubro de 1914. Autoriza a concessão gratuita de terras devolutas até o máximo de cem hectares cada lote. Diário Oficial do Estado do Pará, Belém, 24 de out., 1914.

PARÁ. Decreto n. 3.791, de 31 de janeiro de 1921. Dá novo regulamento ao serviço de terras do Estado. Jornal Folha do Norte, Belém, 24-30 de abr., 1921.

PARÁ. Lei n. 762, de 10 de março de 1954. Dispõe sobre a aquisição gratuita ou onerosa de terras do Estado. Diário Oficial do Estado do Pará, Belém, 19 de mar., 1954.

PARÁ. Lei n. 1.137, de 11 de março de 1955. Estabelece normas sobre a alienação de bens do domínio patrimonial do Estado. Diário Oficial do Estado do Pará, Belém, 13 de mar., 1955.

PARÁ. Lei n. 3.641, de 5 de janeiro de 1966. Dispõe sobre a legislação de terras do Estado e dá outras providências. Diário Oficial do Estado do Pará, Belém, 8 de jan., 1966.

PARÁ. Decreto-lei n. 57, de 22 de agosto de 1969. Dispõe sobre as terras públicas do Estado e dá outras providências. Diário Oficial do Estado do Pará, Belém, 23 de ago., 1969.

PARÁ. Decreto n. 7.454, de 19 de fevereiro de 1971. Regulamenta o Decreto-lei n. 57, de 22 de agosto de 1969, que dispõe sobre as terras públicas do Estado. Diário Oficial do Estado do Pará, Belém, 27 de fev., 1971.

PARÁ. Lei n. 4.584, de 8 de outubro de 1975. Cria o Instituto de Terras do Pará - ITERPA, extingue a Divisão de Terras da Secretaria de Agricultura, modifica o Decreto-lei n. 57/69 e estabelece providências correlatas. Diário Oficial do Estado do Pará, Belém, 17 de out., 1975. 
PARÁ. Constituição de 1989. Constituição do Estado do Pará: promulgada em 5 de outubro de 1989. Organização do texto: Edílson Nery Pinheiro. 1 ed. Pará: Consultoria Geral do Estado, 2011.

PARÁ. Lei n. 7.289, de 24 de julho de 2009. Dispõe sobre a alienação, legitimação de ocupação e concessão de direito real de uso e Permissão de Passagem das terras públicas pertencentes ao Estado do Pará. Diário Oficial do Estado do Pará, Belém, PA, ano CXIX, n. 31.471, p. 5, 29 de jul., 2009.

PARÁ. Decreto n. 2.135, de 26 de fevereiro de 2010. Regulamenta a Lei no 7.289, de 24 de julho de 2009 e o Decreto-Lei Estadual n 57, de 22 de agosto de 1969 para tratar da regularização fundiária nas terras públicas pertencentes ao Estado do Pará e dá outras providências. Diário Oficial do Estado do Pará, Belém, PA, ano CXIX, n. 31615, p. 5, 2 de mar., 2010.

UCHOA, Adelaide Maria Rodrigues; RODRIGUES, Francisco Luciano Lima. Alienação gratuita de bens imóveis públicos em favor de particulares à luz dos princípios constitucionais da eficiência e da economicidade. Revista Jurídica. Curitiba, v. 03, n. 44, p. 535-567, 2016.

VASCONCELOS, Isadora; FISCHER, Luly. A vedação da doação de terrenos públicos à entidades religiosas no Brasil. In: XXV CONGRESSO NACIONAL DE PESQUISA E PÓS GRADUAÇÃO E DIREITO, nºxv, 2016, Brasília. Anais eletrônicos...Brasília: CONPEDI, 2016, p. 59-78. Disponível em:

<https://www.conpedi.org.br/publicacoes/y0ii48h0/e1k54hhs/79eRL1mCSsj4D48u.pdf > Acesso em: 20 out. 2018.

YIN, Robert K. Estudo de caso: planejamentos e métodos. 5 ed. Bookman: Porto Alegre, 2015. ZARELLI, Renata Calheiros; ARAÚJO JÚNIOR, Miguel Etinger de. Regularização fundiária urbana e a instrumentalização da justiça ambiental e social: primeiras impressões da lei federal $\mathrm{n}^{\circ}$ 13.465/2017. Rev. de Direito Sociais e Políticas Públicas. Maranhão, v. 3, p. 41-56, dez. 2017. 